REVIEW ARTICLE

\title{
Формування творчої активності дітей старшого дошкільного віку в процесі інтеграції різних видів діяльності
}

\author{
Вклад Автора: \\ A - Study design; \\ B - Data collection; \\ C - Statistical analysis; \\ D - Data interpretation; \\ E - Manuscript preparation; \\ F - Literature search; \\ G - Funds collection
}

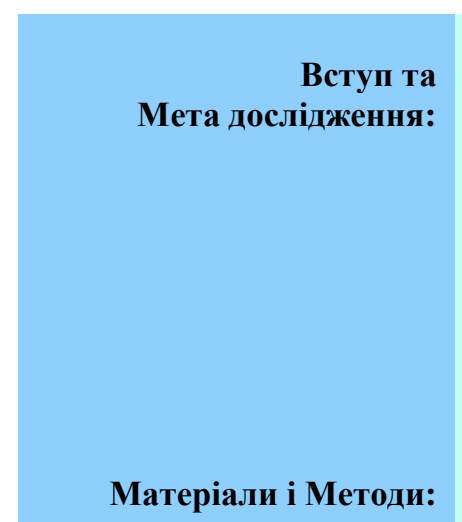

Результати:

Висновки:

Ключові слова:

Копірайт:

DOI та УДК

Конфлікт інтересів:

Рецензування:

Джерело фінансування:

Інформація про автора:

\author{
Котелянець Ю. С. 1 ABDEFG \\ ${ }^{1}$ Центральноукраїнський державний педагогічний університет \\ імені Володимира Винниченка, Украӥна
}

Отримано: 27.02.2020; Прийнято: 26.03.2020; Опубліковано: 30.03 .2020

\section{Анотація}

Сучасний період кардинальних змін життя намого суспільства вимагає від кожної людини прояву гнучкості, немаблонного мислення, ініціативи, здатності продукувати нові ідеї, тобто реалізаиії творчого потенціалу своєї особистості. Вимоги, ше пред'являються суспільством, педагогічною наукою, відносяться й до сучасної дошкільної освіти. Вони включають, пери за все, необхідність створення оптимальних умов для виховання активності творчої особистості, здібностей до повночінної взаємодії з оточуючим середовищем у відповідності зі своїми віковими особливостями й можливостями.

Мета дослідження: обтрунтувати необхідність формування творчої активності дітей старшого дошкільного віку в прочесі інтеграиії різних видів діяльності.

Для досягнення мети в роботі використаний комплекс теоретичних методів дослідження: вивчення та історико-логічний аналіз психолого-педагогічної літератури, синтез, порівняння, узагальнення.

У дослідженні обтрунтовано актуальність створення умов для формування творчої активності дітей дошкільного віку. Акцентовано увагу, щзо творча активність дітей старшого дошкільного віку є діяльний стан особистості, щяо характеризується прагненням до перетворення чого-небудь, створення особистісно значущзого матеріального або духовного продукту. Значну увагу приділено з'ясуванню значення використання в освітньому процесі закладу дошкільної освіти інтеграції різних галузей знань.

Виділено компоненти творчої активності: мотиваційний, креативний, когнітивний, емоційний $i$ вольовий. Встановлено, щ̧о організація процесу формування творчої активності неможлива без опори на різні види діяльності дітей дошкільного віку: розвиток зв'язного мовлення, словотворчість, образотворча та конструктивна діяльність тощуо. Запропоновано ряд складових, які забезпечать ефективність організації освітнього процесу закладу дошкільної освіти з метою формування творчої активності дітей старшого дошкільного віку.

творча активність, творчість, інтеграція, старший дошкільник, компоненти

( 2020 Котелянецьь Ю. С. Опубліковано в архівах Міжнародного журналу освіти і науки

DOI 10.26697/ijes.2020.1.1; УДК 37.036.5:373.2.016

Автор заявляс про відсутність конфлікту інтересів

Подвійне “сліпе”

Це дослідження не отримало жодного зовнішнього фінансування чи підтримки

Котелянець Юлія Серхї̈вна (Автор-Кореспондент) - http://orcid.org/0000-00033932-1824; youliana15@i.ua; кандидат педагогічних наук, стариий викладач кафедри спеціальної освіти та здоров'я людини; Центральноукраїнський державний педагогічний університет імені Володимира Винниченка; Кропивницький, Украӥна. 


\section{Вступ}

Сучасний період кардинальних змін життя нашого суспільства вимагає від кожної людини прояву гнучкості, нешаблонного мислення, ініціативи, здатності продукувати нові ідеї, тобто реалізації творчого потенціалу своєї особистості.

Проблема творчої самореалізації людини в XXI столітті стає однією з найважливіших у філософії, психології, педагогіці, що зумовило необхідність цілісного педагогічного осмислення дієвих шляхів орієнтації системи освіти на формування творчої активності особистості.

Вимоги, що пред'являються суспільством, педагогічною наукою, відносяться й до сучасної дошкільної освіти. Вони включають, перш за все, необхідність створення оптимальних умов для виховання активності творчої особистості, здібностей до повноцінної взаємодії з оточуючим середовищем у відповідності зі своїми віковими особливостями й можливостями.

Мета дослідження. Обгрунтувати необхідність формування творчої активності дітей старшого дошкільного віку в процесі інтеграції різних видів діяльності.

\section{Матеріали і Методи}

Базовий компонент дошкільної освіти формування творчих здібностей виділяє як найважливіше завдання дошкільної освіти.

Вченими доведено, що саме на даному етапі дитинства закладаються основні напрямки, за якими буде проходити подальший розвиток особистості (Божович, 1968; Венгер, 1968; Лейтес, 1988; Лернер, 1981; Парамонова, 2000; Рубинштейн, 1957 тощо).

У педагогічній науці склалося досить широке уявлення про творчість, в якому можна визначити кілька позицій. 3 об'єктивної точки зору, творчість розуміється як створення нового матеріального або духовного продукту діяльності, процес отримання оригінального продукту (Выготский, 1991; Рубинштейн, 1957). Суб'єктивна позиція характеризує творчість як певні якості особистості (Гилфорд, 1965; Лернер, 1981 тощо). Відповідно до суб'єктивного підходу творчість представляється як характеристика процесу, стилю діяльності (Пономарев, 1976). Але, незважаючи на різноманіття підходів й глибину вивчення проблеми творчості, завдання формування творчої активності дитини досі продовжує залишатися однією 3 ділянок “педагогічної цілини”, як ii визначив ще Сухомлинський (1979).

Основи творчої активності закладаються в дошкільному віці, який $є$ більш сензитивним для формування даної якості особистості (Выготский, 1991; Комарова, 1990; Сакулина, 2006; Флерина, 1961).

Вивчення впливу інтегрованих навчальних програм на формування особистості дитини через дослідження структурних та функціональних компонентів на основі різнорівневих показників висвітлено в роботах Мельник (2002).
Найдавніше уявлення про цілісність навколишнього світу й людини на сучасному етапі знаходить відображення в активному впровадженні інтеграції в практику різних ступенів освіти. Інтегративний підхід дозволяе ліквідувати труднощі в переробці дошкільнятами значного обсягу інформації та лімітом часу на його засвоєння.

Для досягнення мети в роботі використаний комплекс теоретичних методів дослідження: вивчення та історико-логічний аналіз психологопедагогічної літератури, синтез, порівняння, узагальнення.

\section{Результати та Обговорення}

Формування людини 3 активною життєвою позицією в сучасних умовах є однією з актуальних проблем педагогічної теорії й практики. Ініціатива, самостійність, інтерес і творче ставлення надають справжню цінність тому, що робить людина. Особлива важливість формування у дітей дошкільного віку такої індивідуальної якості особистості як творча активність підкреслюється в роботах педагогів, психологів, фізіологів.

Творча активність - це складна інтегральна якість особистості, яка характеризує діяльність людини, спрямовану на вирішення творчих завдань, орієнтованих на використання можливостей особистості, результатом якої $є$ певна новизна, значимість для особистісного зростання.

Теоретичний аналіз літератури дозволив виділити ряд компонентів, що складають творчу активність: мотиваційний, креативний, когнітивний, емоційний i вольовий. Всі вище перераховані компоненти утворюють між собою єдиний комплекс, доповнюючи й взаємодіючи один $з$ одним.

Аналізуючи психолого-педагогічні дослідження 3 проблем творчості в цілому, узагальнюючи досвід вчених і педагогів-практиків 3 питань формування творчої активності, ми прийшли до висновку, що творча активність дітей старшого дошкільного віку $\epsilon$ діяльний стан особистості, що характеризується прагненням до перетворення чого-небудь, створення особистісно значущого матеріального або духовного продукту.

Визначаючи таким чином творчу активність, ми підкреслюємо іiі як цілісну особистісну індивідуальність, що володіє деякими критеріальними характеристиками. Складний структурний склад творчої активності не дозволяє в рамках одного дослідження визначити ефективність усіх перерахованих вище компонентів. Тому ми вважали за доцільне в нашій роботі виділити три основні складові в структурі творчої активності: мотиваційний компонент; креативний компонент; вольовий компонент.

Як інтегративна якість особистості, представлена мотиваційним, креативним i вольовим компонентом, творча активність має дві характеристики: кількісну й якісну. Кількісна характеристика представлена стандартизованими методиками (Гилфорд, 1965; Дьяченко, 1986). 
Якісна характеристика $є$ зіставленням кількісних показників мотивації, креативності, волі.

В єдності трьох компонентів абстрагування одного неможливо. Креативний компонент становить фундамент творчої активності. Як один з основних в структурі творчої активності дитини, він передбачає здібність породжувати нові ідеї, що відхиляються від традиційних, швидко вирішувати проблемні ситуації. Креативність в психології виступає як здатність дошкільника до творчого вирішення різних проблемних ситуацій, які виникають при здійсненні тієї чи іншої діяльності.

Схильність до творчості - вищий прояв активності людини, здатність створювати щось оригінальне, вона може виступати в будь-якій сфері діяльності. Масштаб творчості може бути різним, але, як зазначає Лейтес (1988), у всіх випадках відбувається виникнення чогось нового. Тому незалежно від того, яка новизна продукту, отриманого в процесі творчої діяльності, об'єктивна чи суб'єктивна, креативний компонент присутній в ній в рівній мірі.

Креативний компонент творчої активності переломлюється через мотиваційний компонент. Поведінка людини збуджується різноманітними потребами й мотивами, сукупність яких характеризує людину, утворює іiі мотиваційну сферу. Саме мотиви визначають спрямованість особистості дитини, наявність або відсутність у неї творчої активності. Формування специфічних збудників поведінки, а саме прагнення до творчості ставить людину в абсолютно нові взаємовідношення 3 навколишньою дійсністю. Ці взаємини характеризуються тим, що людина перестає лише пристосовуватися до обставин, а починає втручатися в них, “творити їх”, а також “творити саму себе” (Богоявленская, 1981).
Вольовий компонент творчої активності аналізується через самостійність дошкільника в процесі виконання творчого завдання (вибір шляху “за зразком", переважно самостійна робота, 3 епізодичною підтримкою педагога), ініціативність і винахідливість в пошуку рішення й виконання творчого завдання. Дослідження показують, що старшим дошкільнятам достатньо лише зорового орієнтування в умовах поставленого завдання, щоб потім відразу здійснити всю послідовність потрібних дій. Це свідчить про розумову регуляцію дитиною своїх дій й розвитку самостійності.

Мотиви й воля, як компоненти творчої активності, тісно взаємопов'язані. Психологами доведено, що до старшого дошкільного віку мотиви вольових дій перебудовуються: спонукання все ясніше виступає як одна з вирішальних умов, що забезпечує стійку й тривалу вольову напругу дитини (Мануйленко, 1948).

Теоретичні пошуки показали, що найбільш доцільно вибрати наступні критеріальні показники сформованості значущих структурних компонентів творчої активності старших дошкільників (рисунок 1):

1. Мотиваційний компонент:

- активний інтерес до пізнання, сприйняття й віддзеркалення в своїй діяльності наявних знань, умінь і навичок;

- допитливість у навчанні, творчій діяльності.

2. Креативний компонент:

- швидкість мислення;

- гнучкість мислення;

- оригінальність продукту творчої діяльності;

- широта категоризації.

3. Вольовий компонент:

- самостійність й ініціатива в застосуванні знайомих способів дії в нових ситуаціях.

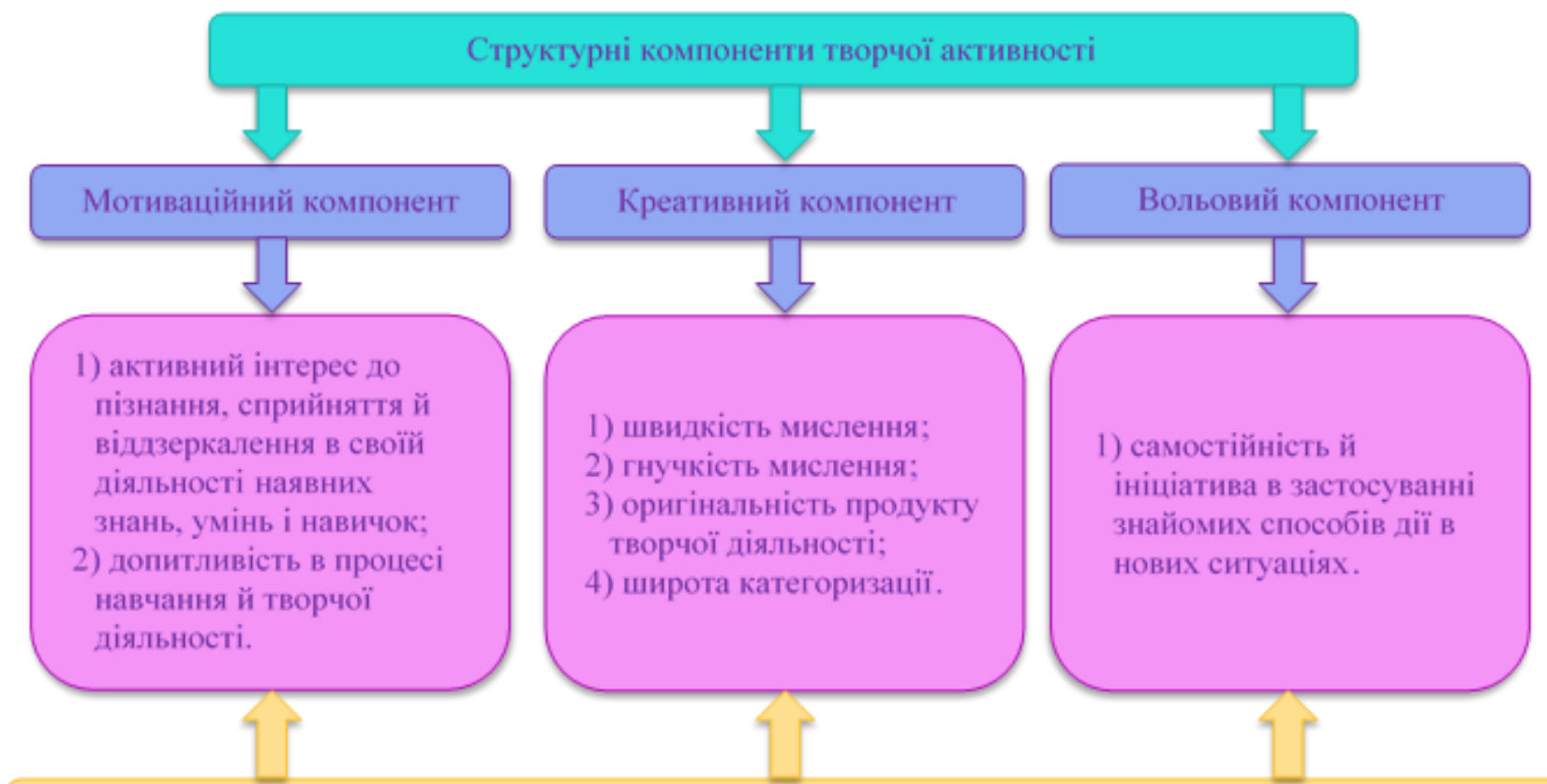

Показники сформованості значущих структурних компонентів творчої активності старших дошкільників

Рисунок 1. Критеріальні показники сформованості значущих структурних компонентів творчої активності старших дошкільників. 
Таким чином, спираючись на тріаду компонентів творчої активності й грунтуючись на значущості навчання в розвитку творчих здібностей, творчої активності дітей старшого дошкільного віку, можна виділити наступні шляхи стимулювання творчої активності дошкільнят в рамках освітнього процесу:

- спрямування дітей на пошук, надання можливості вільного вибору теми творчості;

- включення дошкільнят в усі процеси підготовки до власне творчої діяльності;

- включення в освітній процес гри, ігрових i творчих навчальних ситуацій;

- створення громадської спрямованості занять;

- творчий підхід педагога до керівництва заняттями (створення невимушеної обстановки, варіювання форм, способів організації, взаємозв'язок методів, засобів навчання);

- взаємозв'язок різних видів діяльності.

Доцільно використовувати в освітньому процесі закладу дошкільної освіти інтеграцію різних, раніше розгалужених галузей знань (розвиток мовлення, екологія, фізична культура, музика, образотворча та конструктивна діяльність тощо).

Інтеграція різних освітніх галузей надає можливості динамічного засвоєння знань. Тільки що засвоєні знання завжди включаються в уже наявні. При цьому вони не тільки утворюють ланцюг асоціацій, але одночасно й змінюються, співвідносяться зі знаннями 3 різних галузей. Знання, таким чином, утворюють ієрархічні структури й взаємодіють між собою. Отже, спеціально організоване інтегроване навчання, яке спирається на міжсистемні, внутрішньосистемні асоціації, відкриває грандіозні можливості розвитку логічних форм мислення дітей дошкільного віку, оволодіння ними загальними поняттями, які вимагають динамічного засвоєння знань 3 різних галузей.

Необхідно враховувати, що організація такого роду інноваційної діяльності вимагає спеціальної підготовки педагогічних працівників до іiі упровадження (Melnyk та Pypenko, 2017; 2018).

Побудова освітнього простору закладу дошкільної освіти 3 використанням інтегрованих занять дозволяє:

- здійснювати міждисциплінарні переходи між раніше розгалуженими галузями знань i, отже, створювати нові освітні галузі, що дають цілісну, а не мозаїчну картину світу (Асмолов, 1986; Максимова, 1984 тощо);

- удосконалювати предметну систему, сприяти поглибленню взаємозв'язків і взаємозалежностей між предметами;

- подолати протиріччя: між біологічною та соціальними програмами розвитку дитини; між поглибленим вивченням одного предмета й необхідністю застосування інтегрованих знань в житті (Мельник, 2008);

- гнучко реалізовувати в режимі дня різні види дитячої діяльності, скоротити кількість занять в цілому й їх загальну тривалість, тобто збалансувати необхідність засвоєння значного обсягу інформації та ліміт часу на його засвоєння (Асмолов, 1986);

- пробудити внутрішні резерви дитини до набуття знань, розкриття ï творчого потенціалу; формувати творчу активність (Казакова, 1985; Комарова, 1990; Курочкина, 2000; Сомкова, 1996 тощо).

Організація процесу формування творчої активності неможлива без опори на різні види діяльності дітей дошкільного віку: розвиток зв'язного мовлення, словотворчість, образотворча та конструктивна діяльність тощо.

Згідно 3 дослідженнями важливу роль в творчому процесі дітей дошкільного віку має взаємозв'язок образотворчих видів діяльності й розвитку зв'язного мовлення (Комарова, 1990; Полуянов та Борисовская, 1980 тощо).

Проблема залежності образотворчої діяльності дітей дошкільного віку від розвитку їх мовлення була сформульована ще на початку XX століття Левінштейном, i 3 тих пір $\epsilon$ традиційною для психолого-педагогічних досліджень. Вченими стверджувалося, що процес образотворчої діяльності дітей завжди включає словесну розповідь, що зображення окремих предметів пов'язано із значенням слова, що малюнок дитини без словесного пояснення часто виявляється незрозумілим для оточуючих.

Найважливішою ознакою виразності художнього твору є зв'язки між різними його елементами. У дитячому малюнку такими “елементами” можуть служити зображення окремих істот, предметів, тому що саме окремі зображення виявляються для дитини тією “одиницею”, 3 якою вона діє в малюнку. Зв'язки між елементами можуть виражатися через їх розміщення на аркуші й передачу в малюнку рухів і станів об'єктів. Подібні зв'язки, як вказують Полуянов та Борисовская (1980), можуть міститися і в словесній інтерпретації малюнка, особливо в оповіданнізадумі, що передує процесу зображення. Співвідношення вербальних зав'язків і образотворчих зав'язків у малюнку розкриває залежність між мовою і виразністю його малюнків. 3 метою успішного розвитку виразності дитячого малюнка, формування творчої активності, педагогу, на думку Сомковой (1996), необхідно використовувати вербальні зв'язки. Найбільш ефективними в цьому плані є поетичні твори, усна народна творчість.

Поетичний образ має дві взаємопов'язаних сторони в дитячому зображені творчості: образотворчу й виразну. Зображувальність художнього слова - це його здатність викликати конкретні, зримі образи, представити їх образотворчі якості: колір, форму, пропорції, розташування в загальній картині, деталі. Створені в уяві слухачами живі образи викликають ряд інших образів, які безпосередньо не зображені в творі, тобто художній образ сприяє виробленню асоціацій. Рижовою (2001) також відзначена роль художньо-асоціативних полів у формуванні творчої активності дітей. Залучення різних видів мистецтва, на думку автора, здатне 
порушити в дитині широке коло асоціацій, пов'язаних $з$ іï життєвим і культурним досвідом. Художньо-естетичні асоціації надають індивідуально емоційне й естетичне забарвлення майбутнього твору.

Виразність художнього слова полягає у виділенні головного в образі, узагальненні істотних ознак. Завдяки цьому образ стає відчутним, конкретним, його можна перенести на папір, полотно. До виразних засобів поетичних творів відносяться метафори, порівняння, епітети тощо Через розуміння образного порівняння дитина приходить до самостійного їх створення.

Так, Сомкова (1996) доводить, що в старшому дошкільному віці важливим засобом розвитку творчої активності в мовній діяльності стає опанування образних порівнянь. Навчання дітей вмінню знаходити порівняння в готових літературних творах, самостійно створювати образні порівняння повинно, на думку автора, носити комплексний характер.

Одним з показників розвитку творчої активності особистості, на думку ряду вчених, $є$ цілісність сприйняття дітьми твору мистецтва, під якою розуміється інтеграція форми й змісту (Бабуцкая, 1992). Роль мистецтва в цілому визначена його функціями. Виходячи з основних видів діяльності, Каган (1961) виділив чотири основних функції мистецтва:

\section{1. Пізнавальна.}

Мистецтво розширює знання дитини про життя, додаючи до ii особистого досвіду багатий досвід художника, письменника, композитора, які закріплюють в моральних нормах, політичних ідеях, наукових знаннях.

2. Виховна.

Виховний вплив музики, живопису, літератури можна 3 успіхом використовувати в процесі формування активності особистості. За словами Сухомлинського (1979), виховна сила мистецтва грунтується на тому, що воно змушує людей себе перевиховувати, відчуваючи й переживаючи те, що не довелося їм випробувати й пережити в житті.

3. Гедоністична.

Мистецтво містить в собі не тільки художню, а й специфічну інформацію про творчість і майстерність

художника,

письменника, композитора.

4. Комунікативна.

Роль мистецтва як засобу спілкування полягає в тому, що а) мова мистецтва доступна розумінню всього людства; б) емоційна насиченість художнього образу дозволить глибше проникнути в душі людей; в) воно здатне об'єднати людей на такому духовному рівні, який не підвладний мовній та іншій комунікації.

На сучасному етапі мистецтву віддається ще одна, моделююча, функція. Зокрема, Чумичева (1998, с. 16) вказує, що мистецтво здатне створити модель світу і людини в ньому, розкрити “таємницю" культури. Цим викликана необхідність співіснування різних видів мистецтва, тому що жодне 3 них окремо не може дати досить повну картину світу. Засобом їх об’єднання, на думку автора, є синтез (грец. syntesis - з'єднання, поєднання, органічна єдність).

Функції мистецтва на сучасному етапі наведені на рисунку 2.

Тому так актуальна проблема формування творчо активної особистості вже на етапі дошкільного дитинства, виховання людини, яка вміє творчо використовувати свої знання, займати самостійну позицію по відношенню до зовнішніх умов.

Тріада компонентів творчої активності, виділена нами раніше, підкреслює іï складний інтегративний характер. Тому при розробці технології формування творчої активності дітей старшого дошкільного віку необхідна опора на розвиток показників мотиваційного, креативного та інтелектуального компонентів. В основу даної технології доцільно включити інтеграцію змістовної й діяльнісної сторін освітнього процесу закладу дошкільної освіти. Це, на наш погляд, дозволить:

1. Об'єднати в досягненні єдиної мети раніше розрізнені галузі знань i, тим самим, підвищити мотиваційну спрямованість творчої активності дітей. Зокрема, інтеграція мовленнєвої та образотворчої діяльності відкриває можливість стимулювання інтересу, допитливості, ініціативи й самостійності дошкільників і майбутньої творчості; урізноманітнює зміст дитячих робіт.

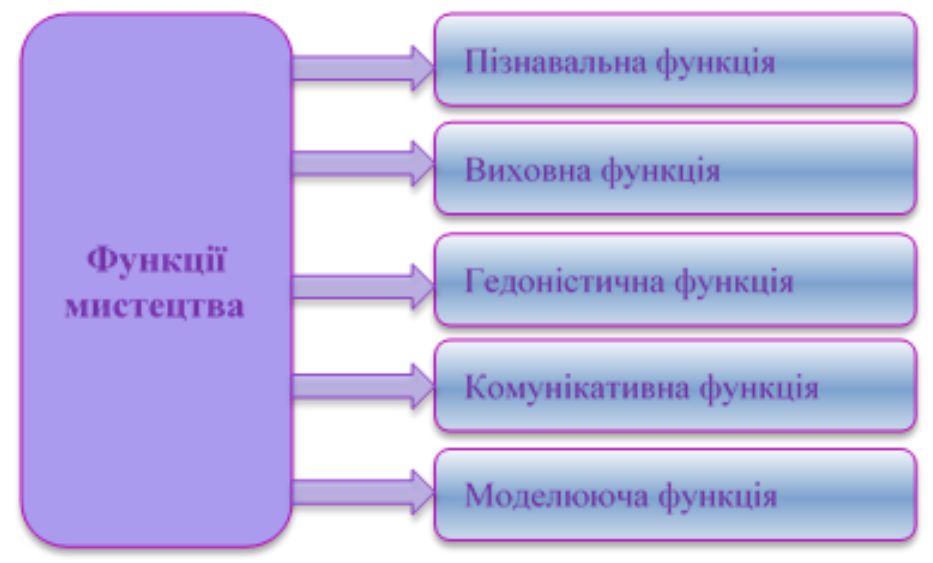

Рисунок 2. Функції мистецтва на сучасному етапі. 
2. Використовувати поряд 3 традиційними незвичайні матеріали й види творчої діяльності дітей 3 метою вдосконалення креативних показників творчої активності. Так, включення в творчість дітей непридатних (пластикові пляшки, кришки тощо), природних (черепашки, солома, листя тощо) матеріалів, оригінальне комбінування їх 3 уже відомими (пластилін, нитки тощо) дає можливість старшим дошкільнятам створювати неординарні творчі роботи.

3. Розглядати певну тему у взаємозв'язку елементів змісту, видів діяльності, що забезпечить цілісне бачення предмета (явища).

\section{Висновки}

Формування творчої активності як вольового акту має на увазі певну організацію освітнього процесу. На наш погляд, формування творчої активності дітей старшого дошкільного віку буде більш ефективним, якщо:

1. Використовувати переважно інтегровані заняття на етапі закріплення основного змісту.

2. Творчий підхід педагога забезпечить варіювання у застосуванні різних методів, засобів і прийомів навчання.

3. Використовувати поряд 3 традиційними незвичайні матеріали для творчості дітей.

4. За допомогою різних мов опису (мова літератури, природи, мистецтва, музики тощо), творчих проблемних ситуацій стимулювати не стільки зовнішню, скільки внутрішню творчу активність (сенсорні та розумові діi).

Таким чином, забезпечиться цілісний підхід, метою якого $€$ сама дитина, iï світосприйняття, світовідчуття, світорозуміння. Не пряме навчання, а пробудження внутрішніх резервів дитини до перетворення знань, стимулювання прихованих напрямків індивідуального розвитку здатні перетворити знання 3 мети на засіб розвитку Людини-творця.

\section{Джерело фінансування}

Це дослідження не отримало жодного зовнішнього фінансування чи підтримки.

\section{Література}

Асмолов А. Г. Психология индивидуальности. Методологические основы развития личности в историко-эволюционном процессе. Москва: Изд-во Моск. ун-та, 1986. $96 \mathrm{c.}$

Бабуцкая Л. А. О взаимоотношениях интеллектуальных и эмоциональных компонентов в художественной деятельности школьников. Игра. Творчество. Одаренность: сб. материалов науч.-практ. семинар. Москва: Росстани, 1992. C. 109.

Богоявленская Д. Б. Пути к творчеству. Москва: Знание, 1981.96 с.

Божович Л. И. Личность и её формирование в детском возрасте. Москва: Просвещение, 1968. $464 \mathrm{c}$.

Венгер Л. А., Пилюгина Э. Г., Венгер Н. Б. Воспитание сенсорной культуры ребёнка от рождения до 6 лет. Москва: Просвещение, $1988.144 \mathrm{c}$.

Выготский Л. С. Воображение и творчество в детском возрасте: психологический очерк. Москва: Просвещение, 1991.93 с.

Гилфорд Дж. Три стороны интеллекта. Психология мылиления/пер. с англ. под ред. А. М. Матюшкина. Москва: Прогресс, 1965. $534 \mathrm{c}$.

Дьяченко О. М. Воображение дошкольника. Москва: Педагогика, 1986. 96 с.

Журавльова Л., І Іпкаєва К. Формування творчих здібностей старших дошкільників засобами інтеграції різних видів художньої-творчої діяльності. Молодь і ринок. 2019. № 1 (168). C. 17-22. doi:10.24919/23084634.2019.158313

Іщенко Л. В., Мельникова О. М. Розвиток дослідницьких здібностей у дітей старшого дошкільного віку. Науковий вісник Ужгородського національного університету. Сер.: Педагогіка. Соціальна робота. 2019. Вип. 2(45). С. 75-79. doi:10.31499/23074906.1.2018.134835

Каган М. С. О прикладном искусстве: Некоторые вопросы теории. Ленинград: "Художник РСФСР”, 1961. 160 c.

Казакова Т. Г. Развивайте у дошкольников творчество: Пособие для воспитателей детского сада. Москва: Просвещение, 1985. $192 \mathrm{c}$.

Комарова Т. С. Изобразительная деятельность в детском саду. Москва: Педагогика, 1990. $231 \mathrm{c.}$

Корякіна I. В., Труш I. А. Розвиток творчості дітей старшого дошкільного віку на засадах вільного вибору образотворчих завдань. Вісник Глухівського національного педагогічного університету імені Олександра Довженка. Сер.: Педагогічні науки. 2019. Вип. 1. С. 174-180. doi:10.31376/2410-0897-2019-1-39-174-180

Костіна В. В. Проектування виховуючого середовища як умова попередження дезадаптацій у дітей та молоді. Сучасна вища $i$ середня освіта в умовах реформування: проблеми, теорія, практика: матеріали наук.-практ. конф., 22 лист. 2013 р. Харків: ХНПУ ім. Г. С. Сковороди, 2013. С. 62-63.

Костіна В. В. Підготовка майбутніх фахівців до створення виховного простору школи як умова профілактики дезадаптації учнів. Вісник Чернігівського національного педагогічного університету. Сер.: Педагогічні науки. 2017. Вип. 144. С. 61-66. doi:10.31651/2524-2660-2019-4-147-154

Курочкина Н. А. Пути развития творческой активности детей старшего дошкольного возраста в процессе приобщения их к русскому декоративно-прикладному искусству. Воспитываем дошкольников 
самостоятельными. С Санк-Петербург: Детство-пресс, 2000. С. 86-92.

Лейтес Н.С. Способности и одаренность в детские годы. Москва: Знание, 1988. 125 с.

Лернер И. Я. Дидактические основы методов обучения. Москва: Педагогика, 1981. 185 с.

Максимова В. Н. Межпредметные связи и совершенствование процесса обучения. Москва: Просвещение, 1984. 123 с.

Мануйленко 3. В. Развитие произвольного поведения у детей дошкольного возраста. Известия АПН РСФСР. 1948. Вып. 14. C. 89-123.

Мельник Ю. Б. Соціально-педагогічна система формування культури здоров'я школярів. Сочіальна робота в Україні: теорія $i$ практика. 2008. № 1. С. 50-56.

Мельник Ю. Б. Формування культури здоров’я учнів початкової школи. Педагогіка, психологія та медико-біологічні проблеми фізичного виховання і спорту. 2002. Вип. 23. C. 37-49.

Парамонова Л. А. Творческое конструирование: психологические и педагогические основы его формирования. Дошкольное воспитание. 2000. № 11. С. 58-64.

Полуянов Ю. Н., Борисовская О. Б. Соотношение вербального и изобразительного в содержании детского рисунка. Психология формирования личности и проблемь обучения/под ред. Д. Б. Эльконина, И. В. Дубровиной. Москва, 1980. С. 29-35.

Пономарев Я. А. Психология творчества и педагогика. Москва: Педагогика, 1976. 280 с.

Ребенок в мире культуры/под ред. Р. М. Чумичевой. Ставрополь: Ставропольсервисшкола, 1998. 558 с.

Рубинштейн С. Л. Принцип творческой самодеятельности. URL: http://rubinsteinsociety.ru/cntnt/nauchnie-raboti/raboti-s-1rubin/princip_tv.html (дата обращения: 14.12.2019).

Рыжова Н. А. Экологическое образование в детском саду. Москва: Изд. дом “Карапуз”, $2001.432 \mathrm{c.}$

Сакулина Н. П. Изобразительная деятельность в детском саду Комарова. Москва: Педагогика, 2006. $256 \mathrm{c.}$

Сомкова О.Н. Развитие творческой речевой активности ребенка 5-6 лет в процессе освоения средств языковой выразительности. Развитие самостоятельности $и$ активности в дошкольном возрасте. СанктПетербург: Акцидент, 1996.

Сухомлинский В. А. Избранные педагогические сочинения. Москва: Просвещение, 1979. $378 \mathrm{c}$.

Флёрина Е. А. Эстетическое воспитание дошкольника. Москва: Изд. АПН РСФСР, $1961.334 \mathrm{c}$.

Шульга Л. Упровадження технології розвитку творчих здібностей дітей дошкільного віку на заняттях із малювання. Актуальні питання гуманітарних наук. 2019. Т. 3. № 23. C. 179-183. doi:10.24919/23084863.3/23.166833

Melnyk Y., Pypenko I. Innovative potential of modern specialist: the essence and content. Psychological and pedagogical problems of modern specialist formation/Yu. B. Melnyk (Ed.). Warsaw: ANAGRAM; Kharkiv: KRPOCH, $2017 . \quad$ P. 9-16. doi:10.26697/9789669726094.2017.9

Melnyk Yu. B., Pypenko I. S. Training of future specialists in higher education institutions. International Journal of Science Annals. 2018. Vol. 1. № 1-2. P. 4-11. doi:10.26697/ijsa.2018.1-2.01

\section{References}

Asmolov, A. G. (1986). Psihologija individual'nosti. Metodologicheskie osnovy razvitija lichnosti v istoriko-jevoljucionnom processe [Psychology of personality. Methodological foundations of personality development in the historical evolutionary process]. Moscow: Izd-vo Mosk. un-ta. [in Russian]

Babuckaja, L. A. (1992). O vzaimootnoshenijah intellektual'nyh i jemocional'nyh komponentov v hudozhestvennoj dejatel'nosti shkol'nikov [On the relationship of intellectual and emotional components in the artistic activity of schoolchildren]. Igra. Tvorchestvo. Odarennost - Game. Creation. Giftedness. Moscow: Rosstani. [in Russian]

Bogojavlenskaja, D. B. (1981). Puti $k$ tvorchestvu [Ways to creativity]. Moscow: Znanie. [in Russian]

Bozhovich, L. I. (1968). Lichnost' $i$ ejo formirovanie $v$ detskom vozraste [Personality and its formation in childhood]. Moscow: Prosveshhenie. [in Russian]

Venger, L. A., Piljugina, Je. G., \& Venger, N. B. (1988). Vospitanie sensornoj kul'tury rebjonka ot rozhdenija do 6 let [Education of the child's sensory culture from birth to 6 years]. Moscow: Prosveshhenie. [in Russian]

Vygotskij, L. S. (1991). Voobrazhenie i tvorchestvo $v$ detskom vozraste: psihologicheskij ocherk [Imagination and creativity in childhood: A psychological essay]. Moscow: Prosveshhenie. [in Russian]

Gilford, Dzh. (1965). Tri storony intellekta [Three sides of the intellect]. In A. M. Matjushkin (Ed.), Psihologija myshlenija - Psychology of thinking. Moscow: Progress. [in Russian]

D'jachenko, O. M. (1986). Voobrazhenie doshkol'nika [The imagination of a preschooler]. Moscow: Pedagogika [in Russian]

Zhuravlova, L., \& Ipkaieva, K. (2019). Formuvannia tvorchykh zdibnostei starshykh doshkilnykiv zasobamy intehratsii riznykh vydiv khudozhnoitvorchoi diialnosti [Formation of creative abilities of senior preschoolers by means of integration of different types of artistic and creative activity]. Molod $i$ rynok - Youth and 
Market, 1(168), 17-22. doi:10.24919/23084634.2019.158313 [in Ukrainian]

Ishchenko, L. V., \& Melnykova, O. M. (2019). Rozvytok doslidnytskykh zdibnostei u ditei starshoho doshkilnoho viku [The development of research skills in older preschool children]. Naukovyi visnyk Uzhhorodskoho natsionalnoho universytetu - Scientific Bulletin of Uzhgorod National University, 2(45), 75-79. doi:10.31499/2307-4906.1.2018.134835 [in Ukrainian]

Kagan, M. S. (1961). O prikladnom iskusstve: Nekotorye voprosy teorii [On applied art: Some questions of theory]. Leningrad: "Hudozhnik RSFSR". [in Russian]

Kazakova, T. G. (1985). Razvivajte u doshkol'nikov tvorchestvo: Posobie dlja vospitatelej detskogo sada [Develop Preschool Creativity: A Handbook for Kindergarten Teachers]. Moscow: Prosveshhenie. [in Russian]

Komarova, T. S. (1990). Izobrazitel'naja dejatel'nost' $v$ detskom sadu [Graphic activities in kindergarten]. Moscow: Pedagogika. [in Russian]

Koriakina, I. V., \& Trush, I. A. (2019). Rozvytok tvorchosti ditei starshoho doshkilnoho viku na zasadakh vilnoho vyboru obrazotvorchykh zavdan [Development of creativity of older preschool children on the basis of free choice of visual tasks]. Visnyk Hlukhivskoho natsionalnoho pedahohichnoho universytetu imeni Oleksandra Dovzhenka - Bulletin of Glukhiv National Pedagogical University named after Alexander Dovzhenko, 1, 174-180. doi:10.31376/2410-0897-2019-1-39-174-180 [in Ukrainian]

Kostina, V. V. (2013, November). Proektuvannia vykhovuiuchoho seredovyshcha yak umova poperedzhennia dezadaptatsii u ditei ta molodi [Designing the educational environment as a condition for preventing maladaptation in children and young people]. Paper presented at the International Conference on Modern Higher and Secondary Education in the Context of Reform: Problems, Theory, Practice (pp. 6263). Kharkiv, Ukraine: KhNPU. [in Ukrainian]

Kostina, V. V. (2017). Pidhotovka maibutnikh fakhivtsiv do stvorennia vykhovnoho prostoru shkoly yak umova profilaktyky dezadaptatsii uchniv [Preparation of future specialists for creation of educational space of the school as a condition of prevention of students' maladaptation]. Visnyk Chernihivskoho natsionalnoho pedahohichnoho universytetu Bulletin of Chernihiv National Pedagogical University, 144, 61-66. doi:10.31651/25242660-2019-4-147-154 [in Ukrainian]

Kurochkina, N. A. (2000). Puti razvitija tvorcheskoj aktivnosti detej starshego doshkol'nogo vozrasta v processe priobshhenija ih $\mathrm{k}$ russkomu dekorativno-prikladnomu iskusstvu [Ways of development of creative activity of children of preschool age in the process of introducing them to Russian decorative and applied art]. Educate preschoolers on their own (pp. 86-92). St. Petersburg: Detstvo-press. [in Russian]

Lejtes, N. S. (1988). Sposobnosti $i$ odarennost' $v$ detskie gody [Abilities and giftedness in childhood]. Moscow: Znanie. [in Russian]

Lerner, I. Ja. (1981). Didakticheskie osnovy metodov obuchenija [Didactic foundations of teaching methods]. Moscow: Pedagogika. [in Russian]

Maksimova, V. N. (1984). Mezhpredmetnye svjazi $i$ sovershenstvovanie processa obuchenija [Interdisciplinary communication and improvement of the learning process]. Moscow: Prosveshhenie. [in Russian]

Manujlenko, Z. V. (1948). Razvitie proizvol'nogo povedenija u detej doshkol'nogo vozrasta [The development of voluntary behavior in preschool children]. Proceedings of the APN of the RSFSR, 14, 89-123. [in Russian]

Melnyk, Yu. B. (2008). Sotsialno-pedahohichna systema formuvannia kultury zdorovia shkoliariv [Socio-pedagogical system of formation of students' health culture]. Sotsialna robota $v$ Ukraini: teoriia i praktyka - Social Work in Ukraine: Theory and Practice, 1, 50-56. [in Ukrainian]

Melnyk, Yu. B. (2002). Formuvannia kultury zdorovia uchniv pochatkovoi shkoly [Forming a health culture for primary school students]. Pedahohika, psykholohiia ta medykobiolohichni problemy fizychnoho vykhovannia $i$ sportu - Pedagogy, Psychology and Medical-Biological Problems of Physical Education and Sports, 23, 37-49. [in Ukrainian]

Paramonova, L. A. konstruirovanie:

(2000). Tvorcheskoe psihologicheskie i pedagogicheskie osnovy ego formirovanija [Creative design: psychological and pedagogical foundations of its formation]. Doshkol'noe vospitanie - Preschool Education, 11, 58-64. [in Russian]

Polujanov, Ju. N., \& Borisovskaja, O. B. (1980). Sootnoshenie verbal'nogo i izobrazitel'nogo v soderzhanii detskogo risunka [Correlation of verbal and fine in the content of children's drawing]. In D. B. Elkonin \& I. V. Dubrovina (Eds.), Psihologija formirovanija lichnosti $i$ problemy obuchenija - Psychology of personality formation and learning problems (pp. 29-35). Moscow. [in Russian]

Ponomarev, Ja. A. (1976). Psihologija tvorchestva $i$ pedagogika [Psychology of creativity and pedagogy]. Moscow: Pedagogika. [in Russian]

Chumicheva, P. M. (Ed.). (1998). Rebenok $v$ mire kul'tury [A child in the world of culture]. Stavropol: Stavropolservisshkola. [in Russian]

Rubinshtejn, S. L. (n. d.). Princip tvorcheskoj samodejatel'nosti [The principle of creative initiative]. Retrieved from: http://rubinstein- 
society.ru/cntnt/nauchnie-raboti/raboti-s-1rubin/princip_tv.html [in Russian]

Ryzhova, N. A. (2001). Jekologicheskoe obrazovanie v detskom sadu [Environmental education in kindergarten]. Moscow: "Karapuz". [in Russian]

Sakulina, N. P. (2006). Izobrazitel'naja dejatel'nost' $v$ detskom sadu Komarova [Visual activities in Komarov kindergarten]. Moscow: Pedagogika. [in Russian]

Somkova, O. N. (1996). Razvitie tvorcheskoj rechevoj aktivnosti rebenka 5-6 let v processe osvoenija sredstv jazykovoj vyrazitel'nosti [Development of creative speech activity of a child of 5-6 years old in the process of mastering the means of language expressiveness]. The development of independence and activity in preschool age. St. Petersburg: Akcident. [in Russian]

Suhomlinskij, V. A. (1979). pedagogicheskie sochinenija

Izbrannye pedagogical compositions].

[Selected Prosveshhenie. [in Russian]

Fljorina, E. A. (1961). Jesteticheskoe vospitanie doshkol'nika [Aesthetic education of a preschooler]. Moscow: Izd. APN RSFSR. [in Russian]

Shulha, L. (2019). Uprovadzhennia tekhnolohii rozvytku tvorchykh zdibnostei ditei doshkilnoho viku na zaniattiakh iz maliuvannia [Introduction of technology of development of creative abilities of preschool children in drawing classes]. Current Issues Humanities, 3(23), 179-183. doi:10.24919/2308-4863.3/23.166833 [in Ukrainian]

Melnyk, Y., \& Pypenko, I. (2017). Innovative potential of modern specialist: The essence and content. In Yu. B. Melnyk (Ed.), Psychological and Pedagogical Problems of Modern Specialist Formation (pp. 9-16.). Warsaw: ANAGRAM; KRPOCH.doi:10.26697/9789669726094.2017.9

Melnyk, Yu. B., \& Pypenko, I. S. (2018). Training of future specialists in higher education institutions. International Journal of Science Annals, 1(1-2), 4-11. doi:10.26697/ijsa.2018.12.01

Formation of Creative Activity of Preschool Children in the Process of Integration of Different Activities

Kotelianets Yu. S. ${ }^{1}$

${ }^{1}$ Volodymyr Vynnychenko Central Ukrainian State

Pedagogical University, Ukraine

\section{Abstract}

Background: The modern period of fundamental changes in the life of our society requires from each person a display of flexibility, non-template thinking, initiative, the ability to produce new ideas, that is, to realize the creative potential of his or her personality. The requirements which are presented by society, pedagogical science, also refer to modern preschool education. They include, first of all, the need to create optimal conditions for nurturing the activity of a creative personality, the ability to fully interact with the environment in accordance with their age characteristics and capabilities.

The aim of the study: to substantiate the need to form creative activity of older preschool children in the process of integration of different activities.

Materials and Methods: To achieve the goal, a set of theoretical research methods were used in the work: the study and historical-logical analysis of psychological and pedagogical literature), synthesis, comparison, generalization.

Results: The study substantiates the relevance of creating conditions for the formation of creative activity of preschool children. It is emphasized that the creative activity of older preschool children is an active state of personality, characterized by the desire to transform something, to create a personally significant material or spiritual product. Much attention has been paid to clarifying the importance of integrating different fields of knowledge in the preschool education process.

Conclusions: The components of creative activity are distinguished: motivational, creative, cognitive, emotional and volitional. It is established that the organization of the process of forming creative activity is impossible without reliance on various activities of preschool children: the development of coherent speech, word-making, visual and constructive activity, etc. A number of components have been proposed that will ensure the effectiveness of organizing the educational process of kindergardens with the aim of forming the creative activity of older preschool children.

Keywords: creative activity, creativity, integration, senior preschooler, components.

\section{Cite this article as:}

Kotelianets, Yu. S. (2020). Formuvannia tvorchoi aktyvnosti ditei starshoho doshkilnoho viku v protsesi intehratsii riznykh vydiv diialnosti [Formation of Creative Activity of Preschool Children in the Process of Integration of Different Activities]. International Journal of Education and Science, 3(1), 8-16. doi:10.26697/ijes.2020.1.1 [in Ukrainian]

The electronic version of this article is complete and can be found online at:
http://ijes.culturehealth.org/index.php/en/arhiv

This is an Open Access article distributed under the terms of the Creative Commons Attribution License, which permits unrestricted use, distribution, and reproduction in any medium, provided the original work is properly cited (http://creativecommons.org/licenses/by/4.0/deed.en). 